\title{
Evaluation of Evapotranspiration Estimation Methods and Development of Crop Coefficients for Groundnut Crop
}

\author{
K. Chandra Sekhar Reddy S.Aruna Jyothy ${ }^{2}$ and P. Mallikarjuna ${ }^{3}$. \\ 1 Professor and Principal, Department of Civil Engineering, Siddhartha Institute of Engineering and \\ Technology, Narayanavanam Road, Puttur-517583, Andhra Pradesh, India. \\ ${ }^{2}$ Assistant Professor, Department of Civil Engineering, S.V.University College of Engineering, Tirupati- \\ 517502, Andhra Pradesh, India. \\ ${ }^{3}$ Professor, Department of Civil Engineering, S.V.University College of Engineering, Tirupati-517502, Andhra \\ Pradesh, India.
}

\begin{abstract}
Evapotranspiration estimation is essential in the planning, designing and management of an irrigation system. The present study aims to compare various reference evapotranspiration (ET $T_{0}$ estimation methods and to develop inter-relationships between ET $T_{0}$ estimated by FAO Penman-Monteith method with those estimated by the other methods. The study also focuses on the comparison of crop coefficients $\left(k_{c}\right)$ recommended by FAO 56 with those computed using the other climatological methods for groundnut crop in the Tirupati region of Andhra Pradesh, India. The evapotranspiration for groundnut crop and other meteorological data observed at the Tirupati Agricultural Research Station were collected from the India Meteorological Department (IMD), Pune. The temperature, radiation, physically and pan evaporation based methods were chosen for comparison in the present study. The results indicated that the Blaney-Criddle, Jensen-Haise and Radiation methods overestimated ET values, Makkink and Pan Evaporation methods underestimated and ET values estimated by Modified Penman, Hargreaves and Priestley-Taylor methods slightly overestimated/ underestimated and were comparable with those computed by Penman-Monteith method(PMM) in the study area. Inter-relationships between PMM and other methods developed may be adopted to get the results in terms of the desired method. The $k_{c}$ values evolved for various methods followed a similar trend to that of FAO 56 and may be adopted to reasonably estimate $E T_{c}$ in the region selecting the method based on the data availability.
\end{abstract}

KEY WORDS: Evapotranspiration; empirical methods; inter-relationships; crop coefficient

\section{INTRODUCTION}

Evapotranspiration is one of the important phases of hydrologic cycle and its accurate estimation is of paramount importance for water balance studies, irrigation system design, crop yield simulation and water resources planning and management. It is desirable to have a method that estimates reasonably the reference crop evapotranspiration $\left(\mathrm{ET}_{0}\right)$. The Penman-Monteith method recommended by UN - FAO and WMO has received widespread acceptance internationally for estimating $\mathrm{ET}_{0}$. However, the major limitation of the method is that it requires data for a large number of weather parameters, which may not be available for many locations.

Crop ET $\left(\mathrm{ET}_{\mathrm{c}}\right)$ is computed by multiplying $\mathrm{ET}_{0}$ with a crop coefficient $\left(\mathrm{k}_{\mathrm{c}}\right)$ to account for the differences between the grass ET and crop ET. Irrigation planning on a regional scale is performed on the basis of estimated $\mathrm{ET}_{\mathrm{c}}$. Doorenbos and Pruitt (1977) recommended crop coefficients for a number of crops grown under different climatic conditions. However, they emphasized the strong need for local calibration of the coefficients under given climatic conditions.

Tyagi et al. (2000) developed crop coefficients for wheat and sorghum from $\mathrm{ET}_{\mathrm{c}}$ measurements and weather data. The relationships between Penman-Monteith method and the other methods were also investigated. Kashyap and Panda (2001) developed regional relationships between lysimeter ET and that estimated by various climatological methods for the Kharagpur region. Irmak et al. (2003) recommended solar radiation and net radiation based $\mathrm{ET}_{0}$ equations over the other commonly used temperature and radiation based methods by comparing their performance with Penman-Monteith method. Temesgen et al. (2005) compared $\mathrm{ET}_{0}$ equations and indicated that $\mathrm{ET}_{0}$ estimated by California Irrigation Management Information System (CIMFIS) Penman equation correlated well with those estimated by standardized Penman - Monteith equation. Alkaeed et al. (2006) compared several $\mathrm{ET}_{0}$ methods for the Itoshima peninsular area, Japan and concluded that the Thornthwaite method was found to have highly correlated with Penman-Monteith method in the study region. Nandagiri and Kovoor (2006) evaluated the performance of several $\mathrm{ET}_{0}$ methods in the major climatic regions of India and identified that the FAO - 56 Hargreaves (temperature based) method yielded $\mathrm{ET}_{0}$ estimates closest to the FAO - 56 Penman-Monteith method in all the climates except the humid one where the Turc (radiation based) method was the best. Demirtas et al. (2007) developed regional relationships between ET and that 
estimated by various climatological methods and concluded that Penman-Monteith method gives the best results followed by Penman, Radiation and Blaney-Criddle methods. Suleiman and Hoogenboom (2007) made a study to assess the potential improvement that can be achieved by replacing Priestley - Taylor with FAO - 56 Penman-Monteith in Georgia and southern states in a humid climate of mountainous and coastal areas. Mallikarjuna and Aruna Jyothy (2008) evolved the performance of various empirical methods for estimating $\mathrm{ET}_{\mathrm{c}}$ for different crops for the Tirupati and Nellore regions of Andhra Pradesh. Xing et al. (2008) evaluated the methods of estimating daily $\mathrm{ET}_{0}$ and found that the pan evaporation methods generated lower estimation of $\mathrm{ET}_{0}$ compared to the Penman-Monteith and Priestley - Taylor methods. The study also suggested the Snyder equation to calculate $\mathrm{k}_{\mathrm{pan}}$ with an acceptable accuracy. Gavilan et al. (2008) compared ASCE and FAO- 56 standardized $\mathrm{ET}_{0}$ equations and indicated that the ASCE method provided good estimations for inland locations of southern Spain. Crop coefficients for potato crop were also estimated at different stages of growth.

The present study reports the performance evaluation of commonly used $\mathrm{ET}_{0}$ estimation methods based on their accuracy of estimation and development of inter-relationships between the Penman-Monteith and the other climatological methods. It also presents the comparison of monthly crop coefficients estimated by various methods based on measured lysimeter $\mathrm{ET}_{\mathrm{c}}$ for groundnut crop for the Tirupati region of Andhra Pradesh.

\section{MATERIALS AND METHODS}

The Tirupati region located in Chittoor district of Andhra Pradesh, India with global coordinates of $13^{0}$ $05^{\prime} \mathrm{N}$ latitude and $79^{\circ} 05^{\prime} \mathrm{E}$ longitudes has been chosen as the study area. The meteorological data at the regional centre for the period 1990-1998 were collected from IMD, Pune. The monthly mean climatic parameters at the station are given in Table 1. The details of the methods selected for the present study are presented in Table 2 .

\section{TABLE-1 MONTHLY MEAN OF WEATHER DATA OF THE STUDY AREA}

\begin{tabular}{|c|c|c|c|c|c|c|c|c|c|}
\hline \multirow{2}{*}{$\begin{array}{c}\text { Mont } \\
\mathrm{h}\end{array}$} & \multirow{2}{*}{$\begin{array}{c}\text { Pan } \\
\text { evaporation } \\
(\mathrm{mm})\end{array}$} & \multirow{2}{*}{$\begin{array}{c}\text { Sunshine } \\
\text { hours } \\
(\%)\end{array}$} & \multicolumn{2}{|c|}{$\begin{array}{c}\text { Vapor pressure } \\
(\%)\end{array}$} & \multirow{2}{*}{$\begin{array}{l}\text { Wind } \\
\text { speed } \\
(\mathrm{kmph})\end{array}$} & \multicolumn{2}{|c|}{$\begin{array}{l}\text { Relative humidity } \\
(\%)\end{array}$} & \multicolumn{2}{|c|}{$\begin{array}{c}\text { Temperature } \\
\left({ }^{0} \mathrm{C}\right)\end{array}$} \\
\hline & & & Max. & Min. & & Max. & Min. & Max. & Min. \\
\hline Jul & 5.85 & 4.02 & 19.32 & 18.49 & 10.52 & 70.37 & 50.23 & 34.18 & 25.10 \\
\hline Aug & 6.02 & 4.96 & 19.28 & 18.39 & 10.15 & 71.52 & 51.34 & 33.67 & 25.01 \\
\hline Sep & 5.36 & 5.70 & 20.01 & 19.09 & 6.82 & 74.61 & 53.77 & 33.56 & 24.24 \\
\hline Oct & 3.85 & 5.30 & 20.72 & 19.80 & 4.81 & 82.89 & 63.64 & 31.53 & 22.65 \\
\hline Nov & 3.37 & 5.50 & 19.84 & 19.27 & 5.47 & 83.81 & 67.63 & 29.55 & 21.43 \\
\hline
\end{tabular}

TABLE-2 DETAILS OF VARIOUS EVAPOTRANSPIRATION ESTIMATION METHODS

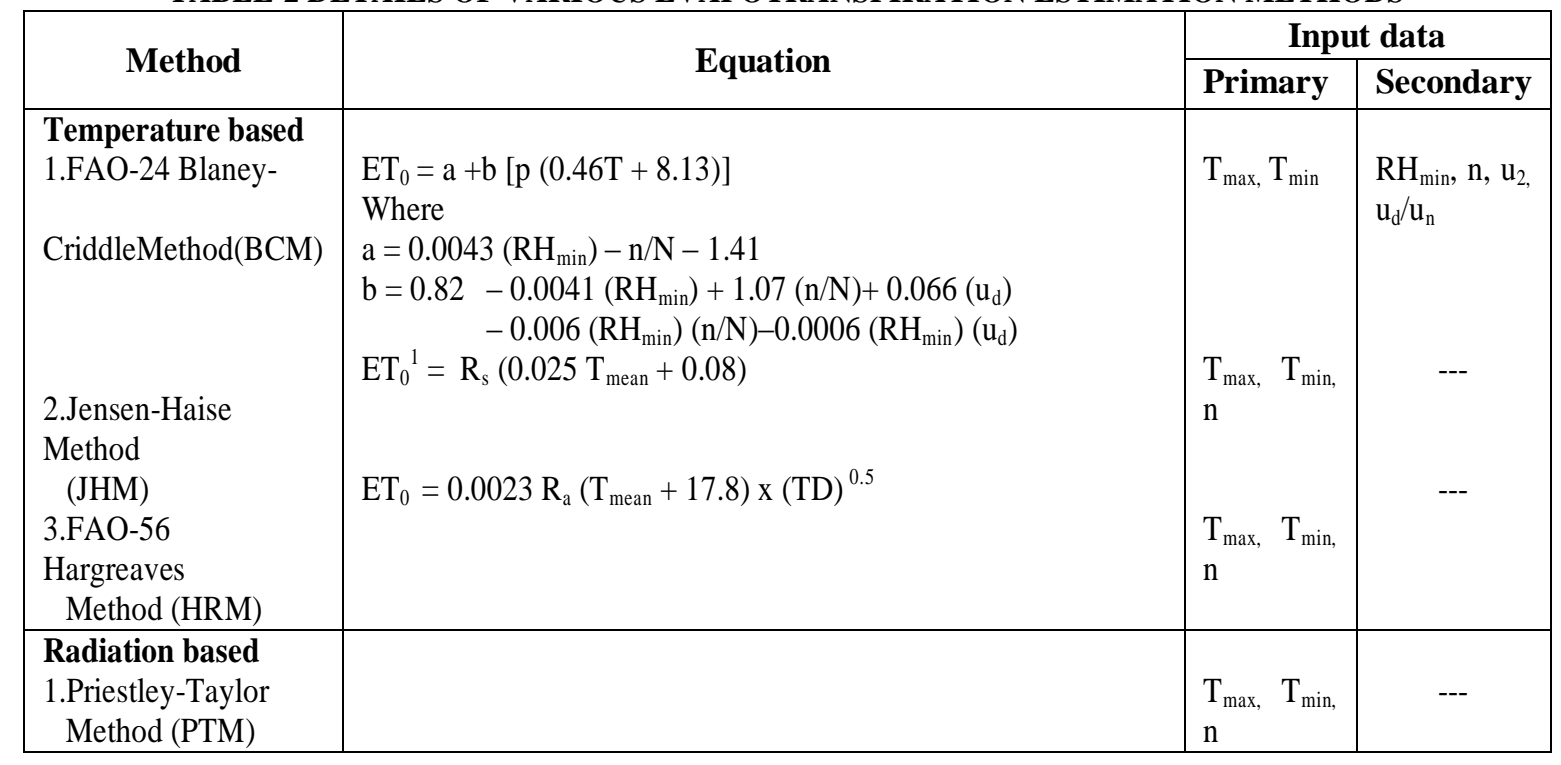




\begin{tabular}{|c|c|c|c|}
\hline $\begin{array}{l}\text { 2.FAO-24Radiation } \\
\text { Method (RAM) }\end{array}$ & $\begin{array}{l}\mathrm{ET}_{0}=1.26 \frac{\Delta}{\Delta+\gamma}\left(\mathrm{R}_{\mathrm{n}}-\mathrm{G}\right) \\
\mathrm{ET}_{0}=\mathrm{c}\left(\mathrm{W} \cdot \mathrm{R}_{\mathrm{s}}\right) \\
\text { Where } \\
\mathrm{c}=1.066-0.00128 \mathrm{RH}_{\text {mean }}+0.045 \mathrm{u}_{\mathrm{d}}-0.0002 \mathrm{RH}_{\text {mean }} \mathrm{u}_{\mathrm{d}} \\
\quad+0.0000315\left(\mathrm{RH}_{\text {mean }}\right)^{2}-0.00103\left(\mathrm{u}_{\mathrm{d}}\right)^{2} \\
\mathrm{ET}_{0}=0.65 \frac{\Delta}{\Delta+\gamma} \mathrm{R}_{\mathrm{s}}\end{array}$ & $\begin{array}{l}\mathrm{T}_{\max ,}, \mathrm{T}_{\min }, \\
\mathrm{n}\end{array}$ & $\begin{array}{l}\mathrm{RH}_{\max ,} \\
\mathrm{RH}_{\min ,} \quad \mathrm{u}_{2,} \\
\mathrm{u}_{\mathrm{d}} / \mathrm{u}_{\mathrm{n}}\end{array}$ \\
\hline $\begin{array}{l}\text { Physically based } \\
\text { 1.FAO-24 Modified- } \\
\text { Penman Method } \\
\text { (MPM) }\end{array}$ & $\begin{array}{l}\mathrm{ET}_{0}= \\
\mathrm{C}\left[\frac{\Delta}{\Delta+\gamma} R_{n}+\frac{\gamma}{\Delta+\gamma}(0.27)\left(1.0+0.01 U_{2}\right)\left(e_{s}-e_{a}\right)\right] \\
\text { Where } \\
\mathrm{C}=0.68+0.0028\left(\mathrm{RH}_{\max }+0.018\left(\mathrm{R}_{\mathrm{s}}\right)-0.068\left(\mathrm{u}_{\mathrm{d}}\right)+0.013\left(\mathrm{u}_{\mathrm{d}}\right.\right. \\
\left./ \mathrm{u}_{\mathrm{n}}\right) \\
\quad+0.0097\left(\mathrm{u}_{\mathrm{d}}\right)\left(\mathrm{u}_{\mathrm{d}} / \mathrm{u}_{\mathrm{n}}\right)+0.000043\left(\mathrm{RH}_{\max }\right)\left(\mathrm{R}_{\mathrm{s}}\right)\left(\mathrm{u}_{\mathrm{d}}\right) \\
\mathrm{ET}_{0}=\frac{0.408 \Delta^{1}\left(R_{n}^{1}-G^{1}\right)+\gamma^{1} \frac{900}{T_{\text {mean }}+273} u_{2}\left(e_{s}^{1}-e_{a}^{1}\right)}{\Delta^{1}+\gamma^{1}\left(1+0.34 u_{2}\right)}\end{array}$ & $\begin{array}{l}\mathrm{T}_{\max }, \mathrm{T}_{\min ,} \\
\mathrm{RH}_{\max }, \\
\mathrm{RH}_{\min ,}, \mathrm{u}_{2} \\
\mathrm{n}\end{array}$ & $\mathrm{u}_{2,}, \mathrm{u}_{\mathrm{d}} / \mathrm{u}_{\mathrm{n}}$ \\
\hline $\begin{array}{l}\text { Pan Evaporation } \\
\text { based } \\
\text { 1.FAO-56 Pan } \\
\text { Evaporation } \\
\text { Method (PEM) }\end{array}$ & $\begin{aligned} \mathrm{ET}_{0} & =\mathrm{K}_{\mathrm{p}} \mathrm{E}_{\text {pan }} \\
\text { where } & \\
\mathrm{K}_{\mathrm{p}}= & 0.108-0.0286 \mathrm{u}_{2}+0.0422 \ln (\mathrm{FET})+0.1434 \ln \left(\mathrm{RH}_{\text {mean }}\right) \\
& \quad-0.000631[\ln (\mathrm{FET})]^{2} \ln \left(\mathrm{RH}_{\text {mean }}\right)\end{aligned}$ & $E_{p a n}$ & $\begin{array}{l}\text { FET, } \mathrm{RH}_{\text {max, }} \\
\mathrm{RH}_{\text {min, }}, \mathrm{u}_{2}\end{array}$ \\
\hline $\begin{array}{l}\text { 2.Christiansen } \\
\text { Method (CSM) }\end{array}$ & $\begin{array}{l}\mathrm{ET}_{0}=0.473 \mathrm{R}_{\mathrm{a}} \mathrm{C}_{\mathrm{T}} \mathrm{C}_{\mathrm{W}} \mathrm{C}_{\mathrm{H}} \mathrm{C}_{\mathrm{S}} \mathrm{C}_{\mathrm{E}} \mathrm{C}_{\mathrm{M}} \\
\text { where } \\
\mathrm{C}_{\mathrm{T}}=0.393+0.5592\left(\mathrm{~T} / \mathrm{T}_{\mathrm{m}}\right)+0.04756\left(\mathrm{~T} / \mathrm{T}_{\mathrm{m}}\right)^{2} \\
\mathrm{C}_{\mathrm{W}}=0.708+0.3276\left(\mathrm{U}_{2} / \mathrm{U}_{2 \mathrm{~m}}\right)-0.036\left(\mathrm{U}_{2} / \mathrm{U}_{2 \mathrm{~m}}\right)^{2} \\
\mathrm{C}_{\mathrm{H}}=1.25-0.212\left(\mathrm{RH} / \mathrm{RH}_{\mathrm{m}}\right)-0.038\left(\mathrm{RH}_{\mathrm{R}} / \mathrm{RH}_{\mathrm{m}}\right)^{5} \\
\mathrm{C}_{\mathrm{S}}=0.542+0.64\left(\mathrm{~s}_{\mathrm{p}} / \mathrm{s}_{\mathrm{pm}}\right)-0.4992\left(\mathrm{~s}_{\mathrm{p}} / \mathrm{s}_{\mathrm{pm}}\right)^{2}+0.3174\left(\mathrm{~s}_{\mathrm{p}} / \mathrm{s}_{\mathrm{pm}}\right)^{3} \\
\mathrm{C}_{\mathrm{E}}=0.970+0.030\left(\mathrm{E} / \mathrm{E}_{\mathrm{m}}\right) \\
\mathrm{C}_{\mathrm{M}}=\text { ranges from } 0.9 \text { to 1.1depending on the latitude }\end{array}$ & --- & $\begin{array}{l}\mathrm{T}_{\max }, \mathrm{T}_{\min }, \\
\mathrm{u}_{2,} \mathrm{RH}_{\max } \\
\mathrm{RH}_{\min }, \mathrm{n}, \mathrm{E}\end{array}$ \\
\hline
\end{tabular}

\section{RESULTS AND DISCUSSION}

The mean monthly $\mathrm{ET}_{0}$ values estimated by various methods are compared with those estimated by FAO 56 PMM as shown in Fig 1. The percent deviations of mean monthly $\mathrm{ET}_{0}$ values with respect to PMM are presented in Table 3. The positive deviation represents overestimation and negative deviation represents underestimation of $\mathrm{ET}_{0}$.

The BCM, RAM and JHM overestimated average monthly $\mathrm{ET}_{0}$ during monsoon period in the study area. The percent deviation has increased as the monsoon progresses. The MKM, PEM and MPM underestimated average monthly $\mathrm{ET}_{0}$ and the deviation decreased mostly as the monsoon advances. The HRM and PTM slightly underestimated during south-west monsoon and overestimated during north-east monsoon. This may be due to the fact that apart from radiation, temperature difference and the corresponding vapour pressure influence more during the period. The CSM followed a similar trend with relatively large percent deviation.

The comparison of monthly $\mathrm{ET}_{0}$ values estimated by various methods with those of PMM is presented in Fig.2. Linear regression analysis has been carried out to derive interrelationships between PMM and other 
methods as presented in Table 4. All the methods except CSM correlated well with PMM during the crop period for the study region. These relationships, therefore, may be adopted to estimate $\mathrm{ET}_{0}$ by the methods for which meteorological data are available to get reasonable estimation in terms of the desired method.

Monthly crop coefficients $\left(\mathrm{k}_{\mathrm{c}}\right)$ were computed for groundnut crop based on the lysimeter measured $\mathrm{ET}_{\mathrm{c}}$ and, $\mathrm{ET}_{0}$ estimated by various methods as presented in Table 5. Comparison of these $\mathrm{k}_{\mathrm{c}}$ values with those recommended by FAO 56 as shown in Fig 3 indicates that all the climatological methods except MKM, PTM, PEM and CSM underestimated during the crop period. The PTM and CSM gave reasonably good estimation during south-west monsoon period and the MKM during north-east monsoon. PEM consistently slightly overestimated $\mathrm{k}_{\mathrm{c}}$ during the crop period.

From the results of the study, it may be observed that HRM, PTM and MPM may be used to estimate $\mathrm{ET}_{0}$ as the values are close to PMM. The PEM may be adopted to estimate $\mathrm{ET}_{\mathrm{c}}$ with the $\mathrm{k}_{\mathrm{c}}$ values recommended by FAO 56. Further, the suitable method depending upon the availability of data may be selected with the corresponding $\mathrm{k}_{\mathrm{c}}$ values suggested to reasonably estimate $\mathrm{ET}_{\mathrm{c}}$ for groundnut crop in the study area.
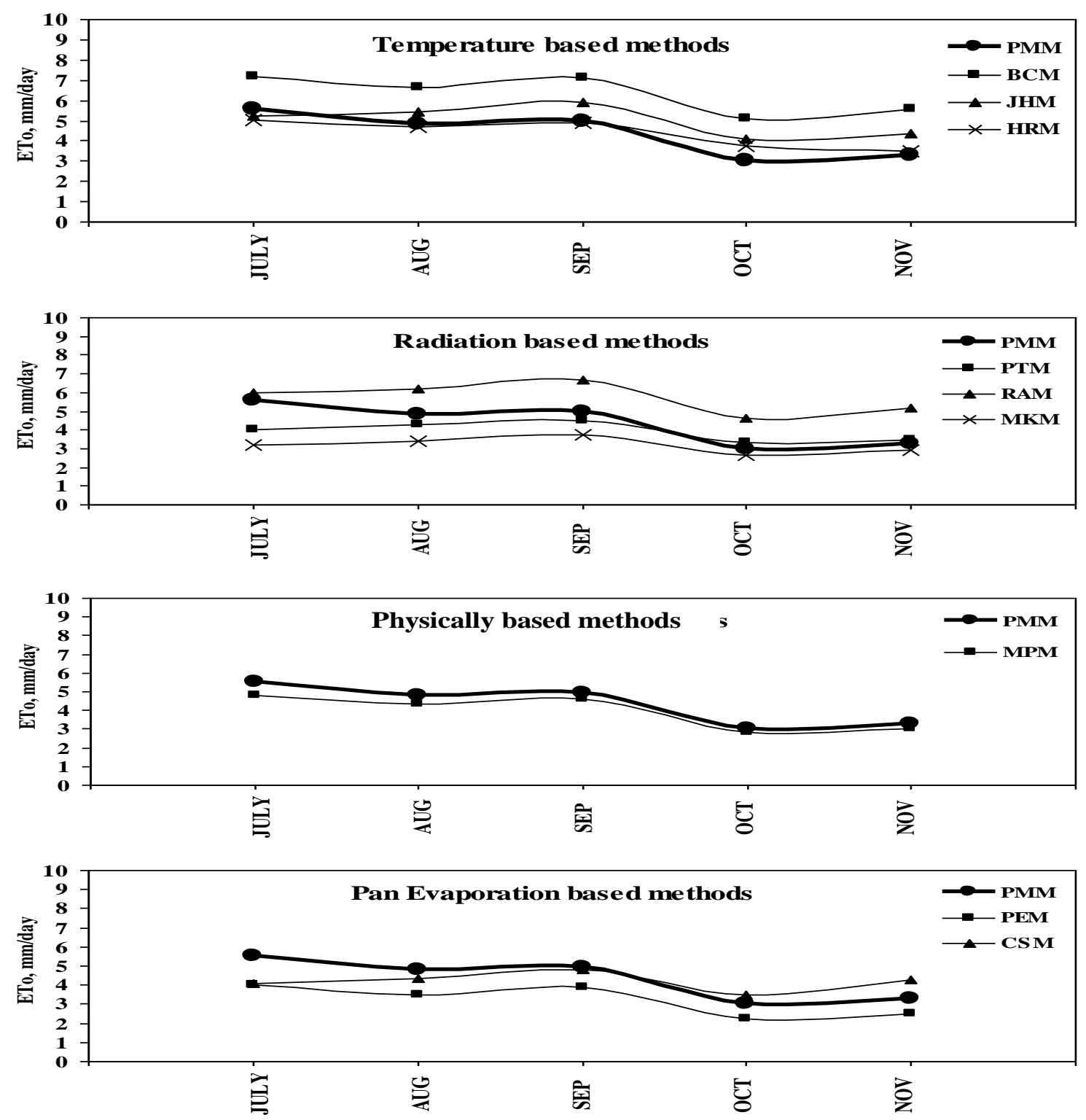

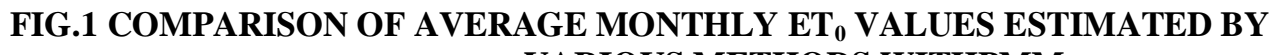

VARIOUS METHODS WITHPMM 
Evaluation of Evapotranspiration Estimation Methods and Development of CropCoefficients

TABLE-3 PERCENT DEVIATIONS OF AVERAGE MONTHLY ET VALUES $^{\text {VAL }}$ ESTIMATED BY VARIOUS METHODS WITH PMM

\begin{tabular}{|c|c|c|c|c|c|c|c|c|c|}
\hline $\begin{array}{l}\text { Method } \\
\text { Month }\end{array}$ & BCM & JHM & HRM & PTM & RAM & MKM & MPM & PEM & CSM \\
\hline Jul & 30.0 & -6.1 & -8.9 & -27.3 & 8.1 & -42.0 & -13.9 & -28.1 & -25.9 \\
\hline Aug & 37.9 & 12.7 & -1.9 & -11.4 & 28.3 & -29.1 & -9.4 & -27.8 & -10.3 \\
\hline Sep & 43.4 & 19.7 & -1.0 & -9.4 & 34.6 & -24.9 & -6.2 & -22.2 & -2.8 \\
\hline Oct & 69.6 & 36.2 & 25.4 & 10.0 & 52.7 & -10.7 & -5.7 & -25.4 & 16.8 \\
\hline Nov & 71.1 & 34.0 & 6.4 & 5.8 & 58.1 & -9.8 & -6.6 & -23.0 & 31.0 \\
\hline
\end{tabular}
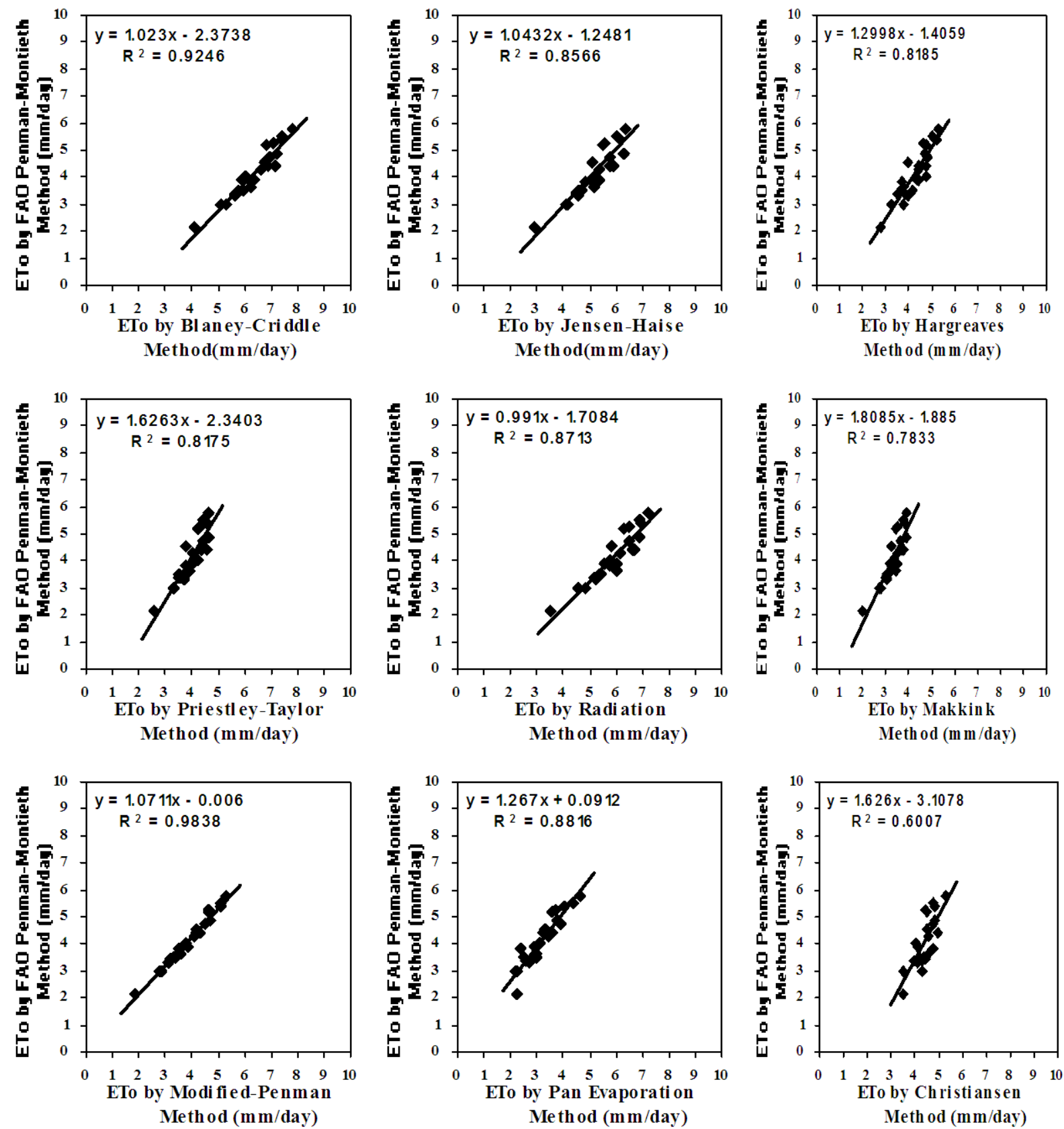

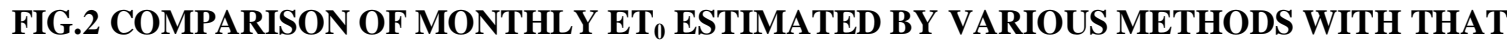
ESTIMATED BY PMM 
Evaluation of Evapotranspiration Estimation Methods and Development of CropCoefficients

\section{TABLE-4 INTERRELATIONSHIPS BETWEEN VARIOUS EMPIRICAL METHODS AND PMM}

\begin{tabular}{|c|l|c|c|}
\hline S.No & \multicolumn{1}{|c|}{ Conversion equation } & $\mathbf{R}^{2}$ & $\begin{array}{c}\text { RMSE } \\
\text { (mm/day })\end{array}$ \\
\hline 1 & $\mathrm{PMM}=1.0230 \mathrm{BCM}-2.3738$ & 0.925 & 1.2 \\
\hline 2 & $\mathrm{PMM}=1.0432 \mathrm{JHM}-1.2481$ & 0.857 & 1.1 \\
\hline 3 & $\mathrm{PMM}=1.2998 \mathrm{HRM}-1.4069$ & 0.819 & 0.5 \\
\hline 4 & $\mathrm{PMM}=1.6263 \mathrm{PTM}-2.3403$ & 0.818 & 0.5 \\
\hline 5 & $\mathrm{PMM}=0.9910 \mathrm{RAM}-1.7084$ & 0.871 & 1.8 \\
\hline 6 & $\mathrm{PMM}=1.8085 \mathrm{MKM}-1.8850$ & 0.783 & 1.0 \\
\hline 7 & $\mathrm{PMM}=1.0711 \mathrm{MPM}-0.0060$ & 0.984 & 0.3 \\
\hline 8 & $\mathrm{PMM}=1.2670 \mathrm{PEM}+0.0912$ & 0.882 & 1.1 \\
\hline 9 & $\mathrm{PMM}=1.6260 \mathrm{CSM}-3.1078$ & 0.601 & 0.7 \\
\hline
\end{tabular}

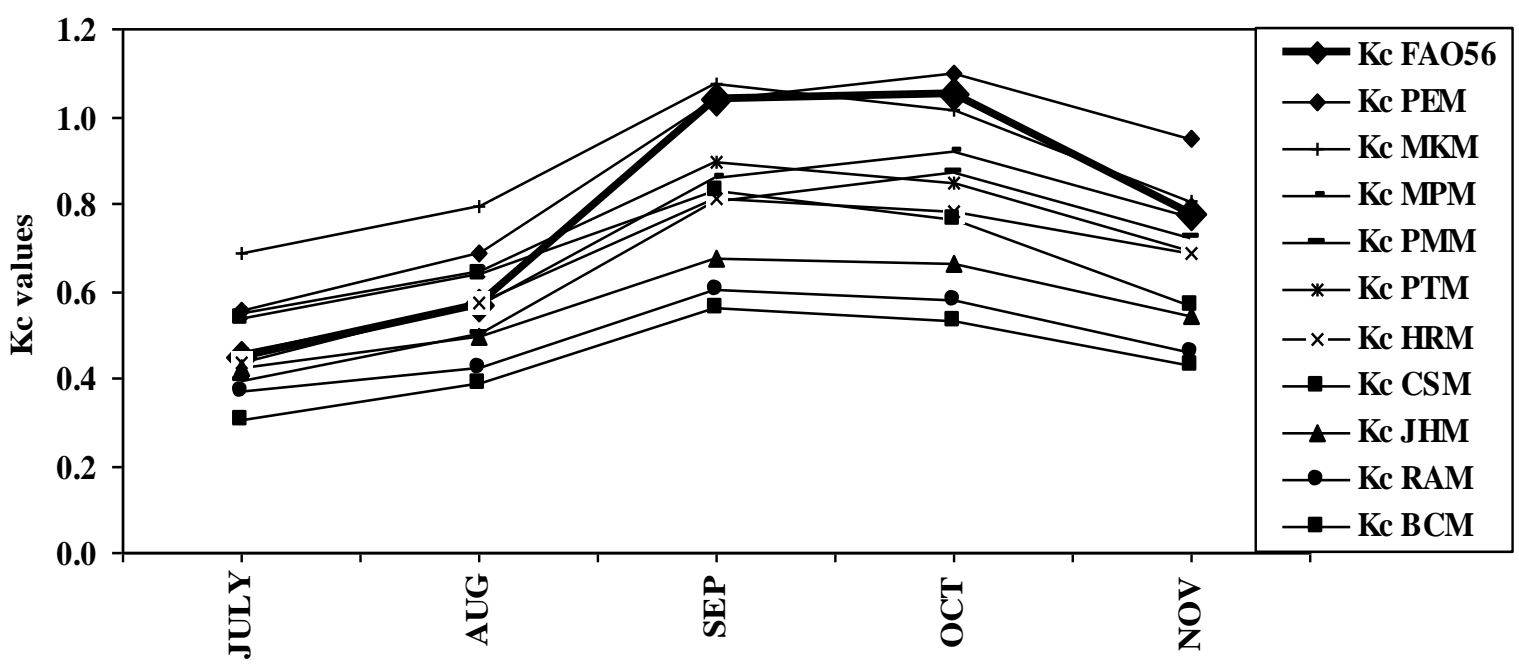

FIG.3 COMPARISON OF MONTHLY CROP COEFFICIENTS $\left(k_{c}\right)$ ESTIMATED FROM MEASURED ET $_{C}$ WITH THOSE RECOMMENDED BY FAO 56

TABLE-5 VALUES OF AVERAGE MONTHLY CROP COEFFICIENTS $\left(\mathbf{k}_{\mathrm{c}}\right)$

\begin{tabular}{|c|c|c|c|c|c|c|c|c|c|c|c|}
\hline \multirow{2}{*}{ Month } & \multicolumn{10}{|c|}{$\mathrm{k}_{\mathrm{c}}$ values } \\
\cline { 2 - 15 } & FAO56 & BCM & JHM & HRM & PTM & RAM & MKM & MPM & PMM & PEM & CSM \\
\hline Jul & 0.5 & 0.31 & 0.42 & 0.44 & 0.55 & 0.37 & 0.68 & 0.46 & 0.40 & 0.55 & 0.54 \\
\hline Aug & 0.6 & 0.39 & 0.49 & 0.57 & 0.65 & 0.43 & 0.79 & 0.57 & 0.50 & 0.69 & 0.64 \\
\hline Sep & 1.0 & 0.56 & 0.68 & 0.81 & 0.89 & 0.60 & 1.08 & 0.86 & 0.81 & 1.04 & 0.83 \\
\hline Oct & 1.1 & 0.53 & 0.66 & 0.78 & 0.85 & 0.58 & 1.01 & 0.92 & 0.87 & 1.10 & 0.76 \\
\hline Nov & 0.8 & 0.43 & 0.54 & 0.69 & 0.69 & 0.46 & 0.81 & 0.77 & 0.72 & 0.95 & 0.57 \\
\hline
\end{tabular}




\section{CONCLUSIONS}

The HRM, PTM and MPM are the alternative methods to PMM for the good estimate of $\mathrm{ET}_{0}$ for the Tirupati region of Andhra Pradesh, India. The inter-relationships developed between the evapotranspiration methods and PMM may be adopted depending upon the data availability to estimate $\mathrm{ET}_{0}$ in terms of the desired method. The $\mathrm{k}_{\mathrm{c}}$ values computed based on the PEM are comparable with those recommended by FAO 56. The other climatological methods adopted in the present study with corresponding $\mathrm{k}_{\mathrm{c}}$ values suggested may also be used to reasonably estimate $\mathrm{ET}_{\mathrm{c}}$.

\section{REFERENCES}

1. Alkaeed, O. et al. (2006). Comparison of Several Reference Evapotranspiration Methods for Itoshima Peninsula Area, Fukuoka, Japan. Memoirs of the Faculty of Engineering, Kyushu University, Vol.66, No.1, pp.1-14.

2. Demirtas, C. et al. (2007). Evaluation of Evapotranspiration Estimation Methods for Sweet Cherry Trees (Prunus avium) in Sub-humid Climate. Pakistan Journal of Biological Sciences, Vol.10 (3), pp. 462-469.

3. Doorenbos, J. and Pruitt, W.O. (1977). Guidelines for predicting crop water requirements. FAO Irrigation and Drainage Paper No.24, FAO, Rome, Italy.

4. Gavilan, P. et al. (2008). Comparison of Standardized Reference Evapotranspiration Equations in Southern Spain. Journal of Irrigation and Drainage Engineering, ASCE, Vol.134, No.1. pp. 1-12.

5. Imark, S. et al. (2003). Solar and Net Radiation- Based Equations to estimate Reference Evapotranspiration in Humid Climates. Journal of Irrigation and Drainage Engineering, ASCE, Vol.129, No.5. pp. 336-347.

6. Kashyap, P.S. and Panda, R.K. (2001). Evaluation of evapotranspiration estimation methods and development of crop-coefficients for potato crop in a sub-humid region. Elsevier, Agricultural water management, Vol. 50, pp. 9-25.

7. Mallikarjuna, P. and Aruna Jyothy, S. (2008). Evapotranspiration Studies for irrigation Projects-A case Study. Journal of the Institution of Engineers (India), Agriculture Engineering Division, vol. 89, pp.5-13.

8. Nandagiri, L. and Kovoor, M, G. (2006). Performance Evaluation of Reference Evapotranspiration Equations across a Range of Indian Climates. Journal of Irrigation and Drainage Engineering, ASCE, Vol.132, No.3. pp. 238-249.

9. Suleiman, A.A. and Hoogenboom, G.(2007). Comparison of Priestley-Taylor and FAO-56 Penman-Monteith for Daily Reference Evapotranspiration Estimation in Georgia. Journal of Irrigation and Drainage Engineering, ASCE, Vol.133, No.2. pp. 175-182.

10. Temesgen, B. et al. (2005). Comparison of Some Reference Evapotranspiration Equations for California. Journal of Irrigation and Drainage Engineering, ASCE, Vol.131, No.1. pp. 73-84.

11. Tyagi, N.K. et al. (2000). Evapotranspiration and crop-coefficients of wheat and sorghum. Journal of Irrigation and Drainage Engineering, ASCE, Vol.126, No.4. pp. 215-222.

12. Xing, Z. et al. (2008). Testing Reference Evapotranspiration Estimation Methods Using Evaporation Pan and Modeling in Maritime region of Canada. . Journal of Irrigation and Drainage Engineering, ASCE, Vol.134, No.4. pp. 417-424.

\begin{tabular}{|c|c|}
\hline$a, b$ & : calibration factors \\
\hline $\mathrm{BCM}$ & : Blaney-Criddle Method \\
\hline c & : adjustment factor \\
\hline $\mathrm{C}$ & : correction or calibration factor \\
\hline $\mathrm{C}_{\mathrm{E}}$ & : elevation coefficient \\
\hline $\mathrm{C}_{\mathrm{H}}$ & : humidity coefficient \\
\hline $\mathrm{C}_{\mathrm{M}}$ & : monthly coefficient \\
\hline $\mathrm{Cs}$ & : sunshine coefficient \\
\hline $\mathrm{C}_{\mathrm{T}}$ & : temperature coefficient \\
\hline $\mathrm{C}_{\mathrm{T}} 1$ & : constant $(\mathrm{JHM})$ \\
\hline $\mathrm{C}_{\mathrm{W}}$ & : wind velocity coefficient \\
\hline $\mathrm{E}$ & : elevation, $\mathrm{m}$ \\
\hline $\mathrm{E}_{\mathrm{m}}$ & : mean elevation of stations considered, $\mathrm{m}$ \\
\hline$E_{\text {pan }}$ & : pan evaporation, $\mathrm{mm} \mathrm{day}^{-1}$ \\
\hline $\mathrm{ET}_{0}$ & grass reference crop evapotranspiration, $\mathrm{mm} \mathrm{day}^{-1}$ \\
\hline $\mathrm{ET}_{0}{ }^{1}$ & : alfalfa reference crop evapotranspiration, $\mathrm{mm}_{\text {day }}{ }^{-1}$ \\
\hline $\mathrm{ET}_{\mathrm{c}}$ & : actual crop evapotranspiration, $\mathrm{mm} \mathrm{day}^{-1}$ \\
\hline$e_{a}$ & : mean actual vapour pressure, mbar \\
\hline $\mathrm{e}_{\mathrm{a}}{ }^{1}$ & : actual vapour pressure, $\mathrm{kP}_{\mathrm{a}}$ \\
\hline $\mathrm{e}_{2}$ & : vapour pressure of the month with the mean maximum temperature, mbar \\
\hline $\mathrm{e}_{1}$ & : vapour pressure of the month with the mean minimum temperature, mbar \\
\hline $\mathrm{e}_{\mathrm{s}}$ & : mean saturation vapour pressure at daily mean air temperature, mbar \\
\hline $\mathrm{e}_{\mathrm{s}}^{1}$ & : saturation vapour pressure, $\mathrm{kP}_{\mathrm{a}}$ \\
\hline FET & : fetch distance, $\mathrm{m}$ \\
\hline $\mathrm{G}$ & : soil heat flux density, mm day ${ }^{-1}$ \\
\hline $\mathrm{G}^{1}$ & : soil heat flux density, $\mathrm{MJ} \mathrm{m}^{-2}$ day $^{-1}$ \\
\hline $\mathrm{H}_{\mathrm{n}}$ & : relative humidity at noon, $\%$ \\
\hline $\mathrm{H}_{\mathrm{nm}}$ & : mean relative humidity at noon over the period considered, $\%$ \\
\hline
\end{tabular}




\begin{tabular}{|c|c|}
\hline HRM & : Hargreaves Method \\
\hline JHM & : Jensen-Haise Method \\
\hline $\mathrm{K}_{\mathrm{p}}$ & : pan coefficient \\
\hline $\mathrm{k}_{\mathrm{c}}$ & : crop coefficient \\
\hline MKM & : Makkink Method \\
\hline MPM & : Modified-Penman Method \\
\hline $\mathrm{n}$ & : actual duration of sunshine in a day, hour \\
\hline $\mathrm{N}$ & : maximum possible sunshine duration in a day (daylight hours), hour \\
\hline $\mathrm{p}$ & : mean daily percentage of total annual sunshine hours \\
\hline $\mathrm{P}$ & : vapour pressure, $\mathrm{mb}$ \\
\hline PEM & : Pan Evaporation Method \\
\hline PTM & : Priestly-Taylor Method \\
\hline $\mathrm{R}_{\mathrm{a}}$ & : extraterrestrial radiation, $\mathrm{mm} /$ day \\
\hline $\mathrm{R}_{\mathrm{a}}{ }^{1}$ & : extra terrestrial radiation, $\mathrm{MJ} \mathrm{m}^{-2}$ day $^{-1}$ \\
\hline $\mathrm{RH}_{\max }$ & : maximum relative humidity, $\%$ \\
\hline $\mathrm{RH}_{\min }$ & : minimum relative humidity, $\%$ \\
\hline RH & : mean relative Humidity, $\%$ \\
\hline $\mathrm{RH}_{\mathrm{m}}$ & : mean of mean relative Humidity over the period considered, $\%$ \\
\hline $\mathrm{R}_{\mathrm{n}}$ & : net solar radiation, $\mathrm{mm}$ day $^{-1}$ \\
\hline $\mathrm{R}_{\mathrm{n}}{ }^{1}$ & : net solar radiation, $\mathrm{MJ} \mathrm{m}^{-2}$ day $^{-1}$ \\
\hline $\mathrm{R}_{\mathrm{s}}$ & : global solar radiation, mm/day \\
\hline $\mathrm{R}_{\mathrm{s}}{ }^{1}$ & : solar radiation reaching the earth, $\mathrm{MJ} \mathrm{m}^{-2} \mathrm{day}^{-1}$ \\
\hline $\mathrm{R}_{\mathrm{ns}}$ & : incoming net shortwave radiation, $\mathrm{MJ} \mathrm{m}^{-2}$ day $^{-1}$ \\
\hline $\mathrm{R}_{\mathrm{nl}}$ & : outgoing net long wave radiation, $\mathrm{MJ} \mathrm{m}^{-2}$ day $^{-1}$ \\
\hline $\mathrm{R}_{\mathrm{so}}$ & : clear sky solar radiation, $\mathrm{MJ} \mathrm{m}^{-2}$ day $^{-1}$ \\
\hline $\mathrm{S}_{\mathrm{p}}$ & : relative sunshine duration, $\mathrm{n} / \mathrm{N}$ \\
\hline $\mathrm{S}_{\mathrm{pm}}$ & : mean relative sunshine duration over the period considered \\
\hline $\mathrm{T}$ & : mean daily temperature, ${ }^{0} \mathrm{C}$ \\
\hline $\mathrm{T}_{\mathrm{m}}$ & : mean daily temperature over the period considered, ${ }^{0} \mathrm{C}$ \\
\hline $\mathrm{T}_{\max }, \mathrm{T}_{\min } \& \mathrm{~T}_{\text {mean }}$ & : maximum, minimum and mean daily temperatures respectively, ${ }^{0} \mathrm{C}$ \\
\hline TD & : difference between maximum and minimum daily temperatures, ${ }^{0} \mathrm{C}$ \\
\hline $\mathrm{T}_{\mathrm{x}}$ & : constant $(\mathrm{JHM})$ \\
\hline $\mathrm{u}_{\mathrm{d}}, \mathrm{u}_{\mathrm{n}}$ & : day and night time wind speeds respectively, $\mathrm{m} / \mathrm{s}$ \\
\hline $\mathrm{u}_{\mathrm{z}}, \mathrm{u}_{2}$ & : wind speed measured at height $\mathrm{z} \mathrm{m}$ and $2 \mathrm{~m}$ respectively, $\mathrm{m} \mathrm{s}^{-1}$ \\
\hline $\mathrm{U}_{2}$ & : wind speed measured at height $2 \mathrm{~m}, \mathrm{~km} \mathrm{day}^{-1}$ \\
\hline $\mathrm{U}_{2 \mathrm{~m}}$ & : mean wind speed measured at height $2 \mathrm{~m}$ over the period, $\mathrm{km}^{-1 a y}{ }^{-1}$ \\
\hline $\mathrm{W}$ & : weighting factor \\
\hline $\mathrm{z}$ & : height of wind measurement, $\mathrm{m}$ \\
\hline$\Delta$ & : slope of saturation vapour pressure curve, $\mathrm{mb}^{0} \mathrm{C}^{-1}$ \\
\hline$\Delta^{1}$ & : slope of saturation vapour pressure curve, $\mathrm{kPa}^{0} \mathrm{C}^{-1}$ \\
\hline$\Upsilon$ & : Psychrometric constant, $\mathrm{mb}^{0} \mathrm{C}^{-1}$ \\
\hline$\Upsilon^{1}$ & : psychrometric constant, $\mathrm{kPa}^{0} \mathrm{C}^{-1}$ \\
\hline
\end{tabular}

